\title{
THE “GABINETTO OF GILDED STUCCO” IN THE ROYAL PALACE OF PORTICI, NAPLES (ITALY): SURVEY AND DIAGNOSIS FOR CONSERVATION
}

\author{
D. Treccozzi ${ }^{1, *}$, A. Pane ${ }^{2}$, A. Sansonetti ${ }^{3}$, R. Catuogno ${ }^{2}$ \\ ${ }^{1}$ Politecnico di Milano, Department of Architecture and Urban Studies - damiana.treccozzi@ polimi.it \\ ${ }^{2}$ University of Naples Federico II - (andrea.pane, raffaele.catuogno)@ unina.it \\ ${ }^{3}$ Consiglio Nazionale delle Ricerche (CNR), CNR-ISPC - antonio.sansonetti@cnr.it
}

Commission II - WG II/8

KEY WORDS: Architecture, Gilded Stucco, Portici, 18th Century, Diagnosis, Conservation

\begin{abstract}
:
During the 18th century architecture in Naples reached an extremely balanced synthesis between architectural spatiality and decorative apparatuses representing the most successful example of local inventiveness over history. Quite an impressive case dating back to that period is represented by the "Gabinetto of gilded stucco" in the Royal Palace in Portici. Located in the area of the palace known as Caramanico - from the name of the owner of the pre-existing building incorporated in the palace - the stucco was molded between 1752 and 1753 by the two stucco workers Angelo la Sala and Gennaro Bruscino, who also decorated the "Salotto di Porcellana" in Chinese style. Today the room, used as an academic department, is affected by quite a serious stucco decay majorly due to negligence and humidity and consisting in efflorescence, powdering and bursting, worsened by the corrosion of metal fixings. However, the present-day state of conservation of these stuccoworks represents a unique opportunity to carefully observe the original technique used to make such artworks at that time. Therefore by means of advanced surveying instruments and multi-analytical material characterization together with archival documents, the present research - set up in collaboration between University of Naples, Politecnico di Milano and CNR - aims at elaborating a thorough knowledge of an emblematic case of 18th century Neapolitan stucco with a view to its future conservation.
\end{abstract}

\section{INTRODUCTION}

Stucco finishes constitute an important part of the 18th century architectural tradition in Naples in terms of significance and diffusion. Despite their importance, not many studies have been expressly devoted to this particular heritage, contrary to other Italian geographical contexts and, as a consequence, Neapolitan traditional finishing techniques are still quite unknown. In order to fill this lack of knowledge, the present research aims at examining an emblematic case study with the hope of drawing more attention to this delicate heritage at risk, whose traces are slowly being wiped out by inappropriate conservation interventions.

The "Gabinetto of gilded stucco" in the royal palace of Portici (Figure 1) in fact is quite an interesting and unique case as it is an interior commissioned by the royal court soon after the arrival of Bourbons in Naples in 1734, which has not been significantly modified over time by restoration interventions, as the present-day decay proves.

Through a multidisciplinary approach including a laserscanning survey, historical researches and a multi-analytical material characterization many features on how stuccoes were made and molded have been revealed. Some of the obtained results of these investigations, still under way, are discussed in the following paragraphs.

\section{THE STUCCO AS A FRAGILE HERITAGE OF 18TH CENTURY ARCHITECTURE IN NAPLES}

\subsection{From history of architecture to construction history}

During the 20th century, the history of architecture has based its analyses on highly selective approaches, which from time to time have highlighted only partial aspects of the buildings, such as space, structural or functional elements, thus sacrificing the unity of architectural conception and neglecting the constructive and decorative aspects. However, even the latter when treated were studied above all by art historians, who are more interested in the formal aspects of these artifacts rather than in their realization. On the other hand, over the last decades there has been a remarkable international growth in the "construction history" sector, which has led to the spread of more systematic and scientifically based studies on the material aspects of architecture.

Thus, almost a century from the birth of the French Nouvelle Histoire and fifty years from the diffusion of studies on the "material culture", developed in the anthropological and archaeological fields (Mannoni, 2003), also the contiguous and interdependent disciplines of the history of architecture and conservation have been greatly enriched in terms of complexity. Following a path that has radiated from North to South through the Italian peninsula the spread of these new approaches in the years 1980-2000, many material aspects of the built heritage of southern Italy, such as walls, vaults, domes and wooden floors, have benefited of relevant insights (Fiengo, Guerriero, 1999; Casiello, 2005; Fiengo, Guerriero, 2008).

\footnotetext{
* Corresponding author
} 


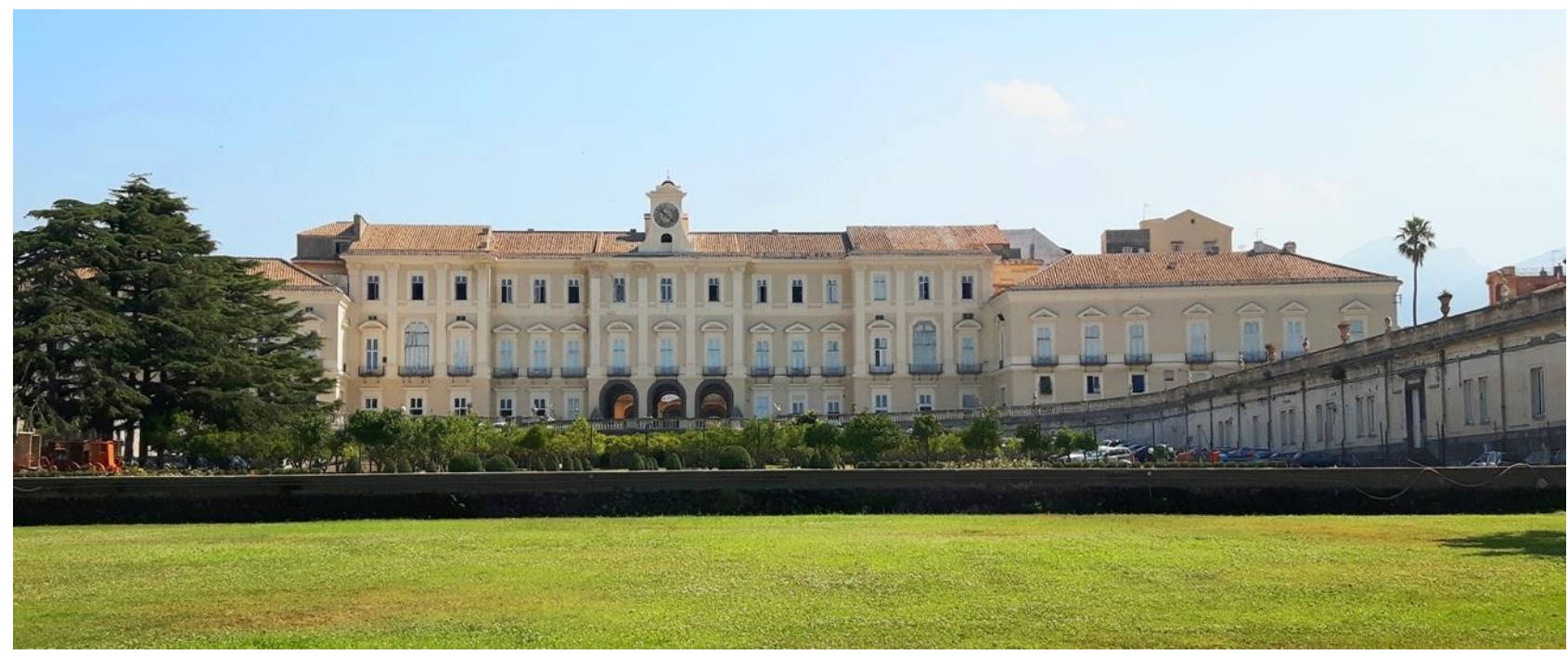

Figure 1. The royal palace in Portici (photo D. Treccozzi 2016)

Architectural finishes remain less investigated, especially in Southern Italy, although a few contributions have tried to explore the field from an archival point of view since the early 1990s (Donadono, Picone, Romeo, Rosi 1990; Russo 2005). In comparison to the deep knowledge on stucco finishes that has been reached in some regions of Northern Italy, as Lombardy, Liguria and Veneto (Arcolao, 1998; Rampazzi, et al., 2008; Doglioni, Scappin, Squassina, 2017), in the other Italian geographical contexts there is still a lot of work to achieve in order to enrich this topic.

Therefore the multidisciplinary study - whose first results are hereby presented - is a response to the current substantial lack of knowledge on these aspects.

\subsection{The need of a multidisciplinary approach}

The research on a fragile heritage such as that of the 18th century stucco can only be carried out with a multidisciplinary approach, in order to overcome the limits that any partial analysis would entail. Hence, it is necessary to intersect the methods of archival research, survey and characterization of materials in the laboratory, following a strictly circular process, in which indirect historical knowledge can support scientific investigations, which alone would lead only to partial results (Grimoldi, 2014).

In the specific case of the Gabinetto of gilded stucco in Portici there is also the extraordinary opportunity of studying samples of the decorative apparatus that has maintained its authenticity, despite the serious losses it has suffered over time, as a result of the absence of maintenance interventions. At the same time, the richness of the archival documentation due to the presence of a royal patronage - allows in this case to carry out a thorough investigation across the board.

The results have already allowed a considerable advancement of knowledge on materials, methods of execution and workers who participated to the production of stucco in the Neapolitan building yard of the mid-18th century. In the following decades, the rich decorative language, at its peak at that time, would have been gradually simplified due to the spread of neoclassicism.

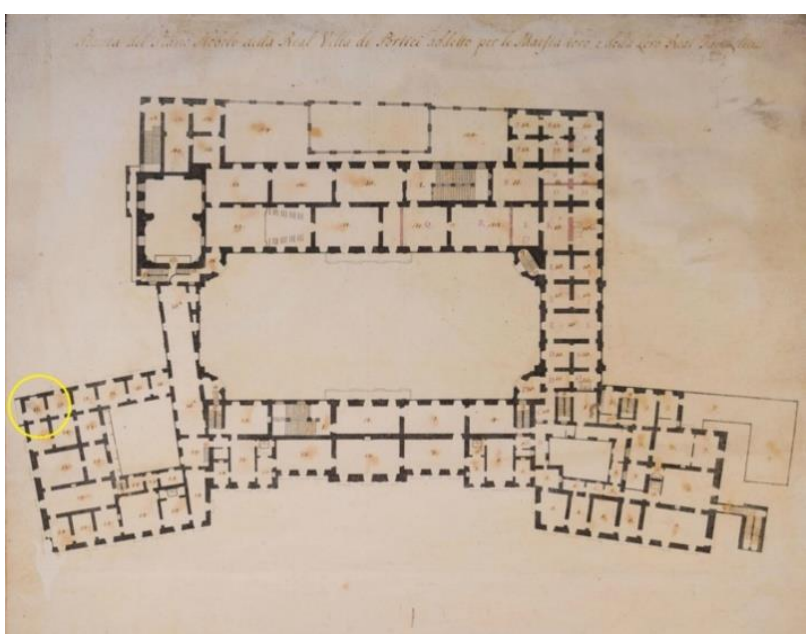

Figure 2. Historic plan of the royal palace in Portici. Main floor with the position of the Gabinetto of gilded stucco (ASNa, Piante e disegni, X-27).

\section{THE “GABINETTO OF GILDED STUCCO”}

\subsection{Description of the interior}

The gilded room is situated in the northwestern corner of the Caramanico area in the royal palace in Portici (Figure 2). It has a square plan and two accesses, the main one and another from the nearby room in addition to two balconies, one of which is set along the ancient Strada Regia delle Calabrie. The four walls and the vault are decorated with gilded stucco; by the way while walls 3 (Figure 7) and 4 display symmetrical decorative compositions, walls 1 (Figure 5) and 2 (Figure 6) differ significantly from the former and between each other. Below the sumptuous cornice, in fact, which is alike in all the walls, the ornamentation changes on the sides, probably due to the presence of the chimney and of the door on wall 1. Finally, the stucco decorations are completed by wall paintings. In smaller ones, major Greek poets and personalities are portrayed such as Archytas on wall 1, Homer on wall 2 and Sappho and Anacreon on wall 3. Unfortunately, those on wall 4 are no longer visible. Larger depictions instead show scenes connected to the characters represented aside. 


\subsection{History of the room}

Since 1738 king Charles of Bourbon gradually acquired estates and private housings in order to construct his new royal palace in the site he had chosen for that purpose (Santoro, 1959; De Seta, Di Mauro, Perone, 1980). In particular, former Caramanico's dwelling was set in the southwestern part of the area and was therefore incorporated within the project by roman architect Antonio Canevari. As the villa was originally a twostorey home, in July 1750 the roofing was demolished in order to construct that part of the main floor of the palace to be allocated to the Queens' apartment ${ }^{1}$, while the preexisting floors would have become the new venue of the Herculanense museum (Allroggen-bedel, Kammerer-grothaus, 1983). Therefore, on top of them, among other rooms, the Gabinetto was constructed. For sure this would have become one of the most outstanding places of the palace together with the socalled "Salotto di Porcellana", later on transferred to the museum of Capodimonte (Santoro, 1959, 224). Nevertheless, the numerous publications devoted to vesuvian villas and specifically to the royal palace in Portici only barely mention the room and its incredible stuccoes.



Figure 3. The Gabinetto of gilded stucco in 1980 (De Seta, Di Mauro, Perone, 1980). The lambris and decorations on the vault and wall on the right were still quite intact and paintings visible.

Though the Gabinetto was long thought to have been made by the painter Clemente Ruta, (Santoro, 1959, 222) recent studies have proved the information wrong (Carotenuto, 1998; Martorelli, 1998). The richly articulated gilded stuccoes, in fact, were molded by a group of artisans involved in the whole great royal palace building site. There were the stucco master of the Royal Palace of Portici Angelo la Sala and his helper Gennaro

1 Archivio di Stato di Napoli (ASNa), Casa Reale Antica (CRA), III inv., Amministrazione generale, 1029.
Bruscino who had worked on the modelling of the stuccoes, Vito Caiazza who applied the gold leaf and Gennaro Pacifico who forged nails and other metal-ware necessary to support mortars. Stucco works were made between October 1752 and June 1753 and the room was concluded around 1754 when crystal glasses were positioned ${ }^{2}$.

Though the room has been scarcely altered over the past century, some slight modifications have probably occurred before and precisely twice after its completion in the $18^{\text {th }}$ century. That is firstly when the French arrived in the Kingdom of Naples between 1806 and 1815 and modified many interiors both to cancel symbols of the former Bourbon dynasty and to make it more appealing to the new Queen's taste and secondly later on with the declaration of the Kingdom of Italy in 1860 when a new overall restyling of the palace was undertaken (Carotenuto, 1998; Martorelli, 1998). As a matter of fact, figurative paintings inserted at the center of the stucco decorations in the gilded room made by Tommaso De Vivo are dated 1860 (Santoro, 1959). Further modifications included the adjustment of missing gold leaves. Sometimes a new gilding was applied on the previous setting a layer of gypsum on top of which other gold leaves were laid, as proven by the presence of gold leaf fragments beneath samples SDRP5 and SDRP9 (see Table 1). Other times, gold discontinuity was compensated by a golden painting layer.

\subsection{Present state of conservation}

The Gabinetto of gilded stucco was originally largely decorated by gilded ornaments. Unfortunately today all the surfaces are affected by severe decay, which has wiped out entire portions of these decorations. Main causes are negligence - for the room has been used up to now as an academic department and furnishings lean on surfaces with no space left in between together with moisture and water infiltrations mainly from the two balconies. Evidence is provided by the observation of a more considerable decay in proximity to the two openings and on the outer walls. The ceiling, for instance, presents missing parts towards the balcony while the parts towards the access corridor show better conditions. Consequently, mortars are affected by efflorescence and powdering, plus by bursting which is worsened by the resulting corrosion of metal fixings. Due to the lack of any recent intervention, today decorative elements are poorly inbuilt into the substrate, therefore every slight pressure causes detachments and fragments continuously fall. No surprise that deterioration has increased over the past years; in fact a picture of one of the corners of the room published in 1980 (De Seta, Di Mauro, Perone, 1980) (figure 3) shows a much greater entirety of the decorative apparatus compared to the present situation.

\section{METHODS}

Despite the importance and diffusion of stuccoes, especially in interiors, during the 18th century in Naples, no specific research on this topic has been undertaken up to now. While many studies specifically devoted to mortars for ornamental uses are registered in other Italian geographical contexts - i.e. Veneto, Lombardy and Sicily - Naples still lacks such an in-depth knowledge on this heritage. Many books regarding Neapolitan traditional building techniques ignore such aspects (Fiengo, Guerriero, 2008) or even simply deduce them from historic treatises (Aveta, 1987), never directly verifying them on architectures. Therefore, the aim of this research is to contribute

\footnotetext{
ASNa, CRA, III inv., Amministrazione generale and Conti e Cautele.
} 
in understanding what stuccoes were made up of, how they were molded and put on-site through the study of emblematic case studies. In this regard, the Gabinetto of gilded stuccoes represents an interesting case since the damages caused by downgrade make it possible to collect samples and observe signs of the working process otherwise not easily observable. Thus, the main objective of this study is to clarify the procedure required by the modelling of stuccoes in order to gain major knowledge on Neapolitan traditional techniques for what gilded stucco is concerned.

The research was carried out with a multidisciplinary approach in order to be able to interpret traces still present in the Gabinetto in a more complete way. The direct on-site observation, the room survey, the multi-analytical material characterization and the historic and archival research together provide complex data capable of making the traditional techniques applied in the gilded room in mid-18th century knowable. In particular, main queries regard: a) composition of stuccoes and possible correlation to specific elements of the decorative apparatus; b) manufacturing process from the preparation of the underlayer to the application and modelling of elements; c) gilding methods.

\subsection{Direct on-site observation}

Before starting the survey and the sample collection, a preliminary study based on direct observation of the room was necessary. Due to the severe decay of the room, a great amount of information could be obtained by simply taking a close look at the surfaces. This includes many signs left by the processing of the stuccoes (i.e. the presence of scraped keying coats visible in correspondence of plaster lacunas and prints left by fallen elements) and all the metal-ware left visible by mortar disintegration (ICOMOS-ISCS 2008). Major causes of decay were quite perceivable as well, for instance the discoloration, efflorescence and missing parts were mainly concentrated in proximity to openings while bursting (ICOMOS-ISCS 2008) was observable next to the metal-ware on walls in contact with the external environment. Therefore, direct observation was keying to gain the aforementioned information in no other way so effectively obtainable. Such data was registered to compare it to further testings' results. However direct observation was also important in order to be able to plan following phases of investigation. In fact, sampling points were planned where the surfaces already showed discontinuity and in a number of points necessary to be representative of each kind of ornament in terms of geometry and type of finish. All the data collected allowed to make an overall interpretation of results and to understand the whole stucco molding and gilding processes.

\subsection{Laser scanner survey}

The extreme richness of the decorative apparatus of the Gabinetto of gilded stucco required a morphometric survey system capable of undertaking an accurate cast of both partially and entirely preserved stuccoes. Survey operations were preceded by a preliminary inspection of the location, necessary to plan survey phases and to determine and identify scans to be performed. Finally, Laser Scanner CAM2 Faro Focus 3D X330 was chosen, being equipped with integrated digital camera with optical axis aligned to the measuring radius and phase shift. In order to cover the whole room, several - even short - scans were necessary to avoid grey areas caused by cornices and furniture. Square targets were placed to register the point cloud always verifying that the same set of three targets was visible on pairs of consecutive scans before performing the acquisition.
In order to operate effectively, particular attention has been paid to the instrument settings keeping in mind the complexity and plasticity of the room: 14 scans were carried out, each lasting 6 minutes and the resolution was 2 points $6 \mathrm{~mm}$ apart on a plane 10 meters from the emitter. The equivalent equirectangular image for each scan is $10240 \times 4267$ and the single point cloud has a size of 43.7 MPts (millions of points) with 3x quality.

Data obtained provided a cast perfectly responding to reality with which a model of the room and its decorative apparatus with related color information was reconstructed. Furthermore, laser scans allowed to acquire dimensional values, generate orthophotos, elaborate three-dimensional models, extract textures and produce spherical photos.

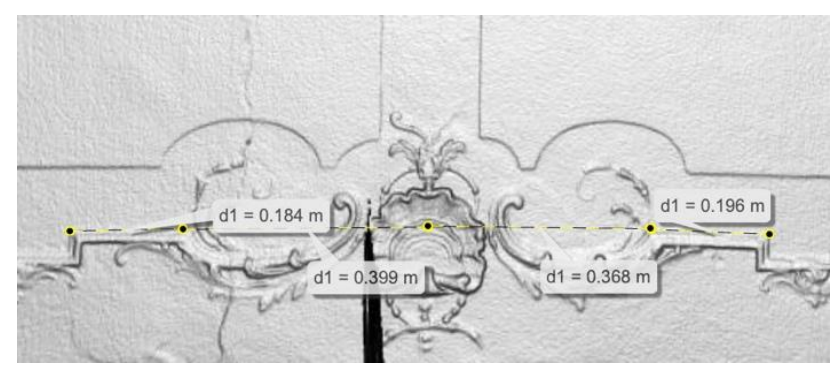

Figure 4. Measurement of stucco ornaments on laser scanner white-meshed model.

The survey performed in the room was fundamental to clear doubts regarding the stucco molding process in which dimensional and morphometric data are decisive. No archival document found, in fact, reveals whether or not the ornaments were prepared using molds. Starting from the premise that the use of molds results in producing identical pieces, it was important to understand if some sets of stucco elements were dimensionally identical to know where and if molds had been used. Thus, the measurement of frames on the threedimensional model revealed slight differences in lengths (in the order of 1 to $5 \mathrm{~cm}$ ) while more elaborate and sinuous moldings showed differences in the radius of curvature. Furthermore, white meshes applied to the model made reliefs more visible. These measures taken on the white-meshed model demonstrated that ornaments had been made by hand, either on site or in the workshop, but certainly without using molds (Figure 4).

Models and orthophotos have been also important to graph all the information, assign metric data to each stucco ornament and, once the characterization phase will be concluded, they will be useful to map stucco composition.

\subsection{Archival research}

The Archivio di Stato di Napoli owns a great quantity of original documents written at the time the royal palace in Portici was constructed. The collection includes voluminous folders containing the whole building activity as expenses were regularly registered. All the laborers ordered materials and most important artisans were listed specifying the current activity carried out to keep record of the payments ${ }^{3}$.

3 ASNa, CRA, III inv., Conti e Cautele. It is important to highlight that the abovementioned archival collection was not unknown to this day as it has been already cited by other scholars (Carotenuto, 1998 and Martorelli, 1998). However, documents were primarily studied to attribute stucco works to their actual authors since until then they were believed to have been made by the painter Clemente Ruta. Therefore, the study of these sources in terms of understanding of traditional techniques is new. 
At times, in order to justify salaries or even just to quantify the works, estimates were made by outer professionals and attached to the register. These evaluation documents - so called apprezziare, in fact, the most interesting sources to study traditional techniques as works were carefully described together with materials used. Gypsum for instance was provided by a man named Antonio Rossi, while gold leaf by the gold-beater Michele Garzilli and marble powder for stuccoes by Francesco Ranzini ${ }^{4}$. Pozzolan and other volcanic products were imported by nearby hamlets, while lime was prepared in the nearby harbor of the Granatello since 1750s when furnaces were built there ${ }^{5}$. Generally, supplies were offered by the royal court, therefore only mastery was evaluated in the apprezzi and payed to craftsmen.

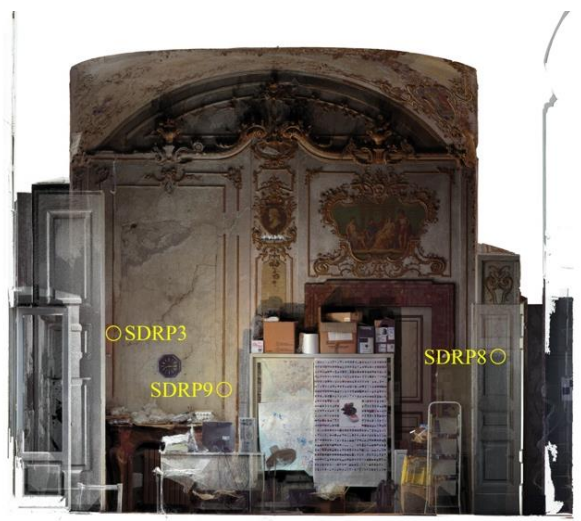

Figure 5. Laser scanner survey of the Gabinetto of gilded stucco. Wall 1 with sampling points.

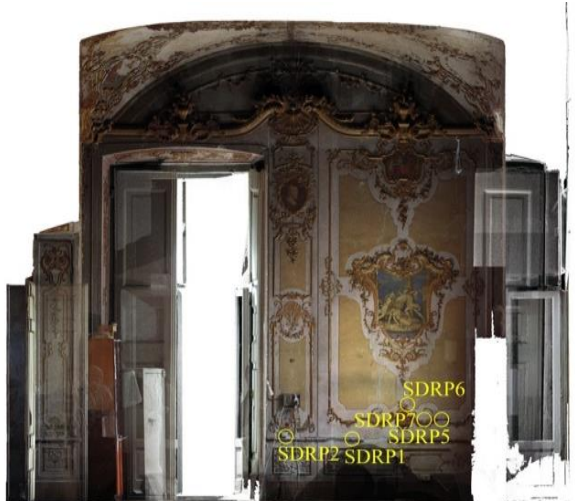

Figure 6. Laser scanner survey of the Gabinetto of gilded stucco. Wall 2 with sampling points.

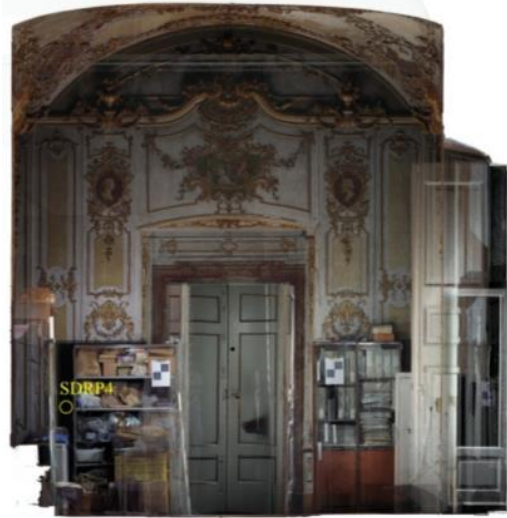

Figure 7. Laser scanner survey of the Gabinetto of gilded stucco. Wall 3 with sampling points.

4 ASNa, CRA, III inv., Conti e Cautele, 1043.

ASNa, CRA, III inv., Conti e Cautele, 1033.
Between 1749 to 1753 there are four apprezzi specifically devoted to the estimate of stucco works done by Angelo la Sala and Gennaro Bruscino ${ }^{6}$ including those in the royal chapel, several other rooms of the palace and some elevations. Generally, the term stucco is used to indicate finishes - either used to make flat surfaces or modelled as frames, both in interiors and exteriors - covering the levelling coat which was to be well flattened and polished. However, while in interiors gypsum is mentioned among the components of levelling coats, in exteriors the "powder from Ischia" is the fundamental element to make mortars hydraulic. The term plaster, instead, is used to indicate paintings' substrates, either frescoes or a secco, and was always called «tonica d'arena» revealing the presence of sand or probably just any clastic non-cemented material.

For what the gilded room is concerned, in the apprezzo the paragraph in entitled «Last Gabinetto, denominated of the bath.... $\gg^{7}$. The document describes the cloister vault and walls covered with very fine stucco decorated with flowers, fruit, leaves, frames and «other tangles and minute works well adapted and adorned in between». To estimate this very fine artwork, two stucco masters were called: Aniello Preziosi came first, but because he visited the room before the lambris was completed, also the very famous Giuseppe Scarola was requested his authoritative opinion as soon as the whole work was accomplished. The room was praised and the salary for the two workers was raised.

In the apprezzi, the application of gold leaf in the gilded room is not mentioned. However, we know from other documents that the artisan to whom the work was entrusted was Vito Caiazza, who gilded other rooms in the royal palace as well. In those very years, in fact, he was working in the royal chapel in which his craft was estimated according to the prices established by the famous Martino Buonocore. In the document, gold is defined as «oro di spada». It is not clear how this kind of gold leaf differed from others, but surely, it costed much more than other types mentioned as the "roman gold" 8 . Perhaps it had a greater purity and thus, more karats. Moreover, in this estimate mainly two techniques are described:

- mordant gilding: applied on stucco modelled surfaces, it consists of two layers of mordant, both containing minium $\left(\mathrm{Pb}_{3} \mathrm{O}_{4}\right)$ and gold leaf.

- gilding with gypsum: it consisted in the application of two layers of glue, well-scraped gypsum, two layers containing minium $\left(\mathrm{Pb}_{3} \mathrm{O}_{4}\right)$ and either gold leaf or copper powder.

Actually, both techniques have been applied over time in the Gabinetto. However only the former - which is a more widely spread technique for stuccoes (Sansonetti, et al., 2016) - was done in the mid-18th century by Caiazza as confirmed by SEM-EDS which shows the presence of the element lead $(\mathrm{Pb})$. The latter instead was applied later on the occasion of a restoration intervention, probably in the 19th century. Evidence to such a result is given by the presence of gold leaf fragments underneath gypsum layers used in the gypsumgilding technique (samples SDRP5 and SDRP9 -Table 1).

\footnotetext{
6 ASNa, CRA, III inv., Conti e Cautele, 1143, 1145, 1148 and 1153

7 ASNa, CRA, III inv., Conti e Cautele, 1153, p. 937-939v.
}

8 ASNa, CRA, III inv., Conti e Cautele, 1143. 


\subsection{Material characterization}

Materials were sampled as shown in figures 5 to 7 to be representative of each kind of ornament in the room and selected from weakly bonded points to minimize damages on surfaces. They were labelled as shown in Table 1. Samples include: horizontal frames dividing the boiserie from the major ornamental part (SDRP1, SDRP2); outer horizontal and vertical frames of the main decorations (SDRP3, SDRP5, SDRP9); ornaments made on-site (SDRP7); ornaments possibly made prior in the workshop (SDRP6, SDRP8); painted finishes (SDRP4). Material characterization is being led with a multianalytical approach: some analyses are still under way, while those already carried out are synthetized in Table 1 .

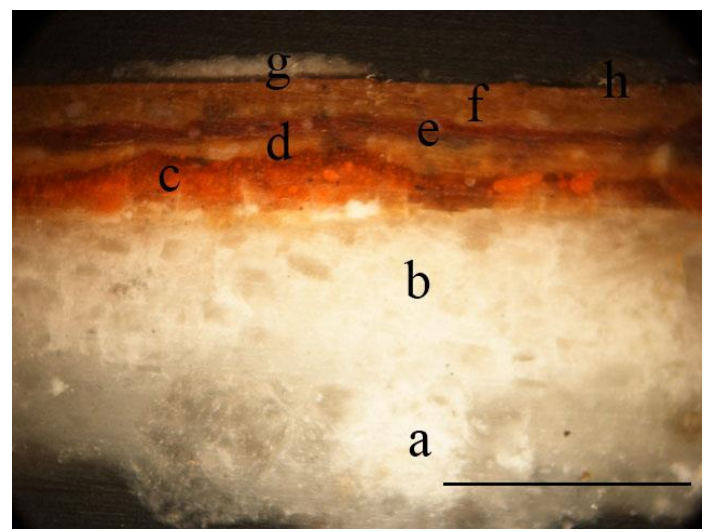

Figure 8. Cross section of SDRP1 showing several layers: (a) gypsum and aerial lime with traces of magnesium; (b) finish lime; (c), (d), (e), (f) sulphur, lead, iron; (g) sulphur, aluminium, iron and other; (h) gold leaf fragments.

\begin{tabular}{|l|l|l|}
\hline $\begin{array}{l}\text { Sample } \\
\text { name }\end{array}$ & Description & Analyses \\
\hline SDRP1 & $\begin{array}{l}\text { Gilded stucco from horizontal } \\
\text { frame above boiserie, wall 2. } \\
\text { SDRP2 } \\
\text { Gilded stucco from horizontal } \\
\text { frame above boiserie, wall 2. } \\
\text { Gilded stucco from vertical } \\
\text { frame, wall 1. }\end{array}$ & $\begin{array}{l}\text { CSP, SMO, } \\
\text { SEM-EDS, } \\
\text { XRPD } \\
\text { CSP, SMO, } \\
\text { SEM-EDS, } \\
\text { XRPD } \\
\text { CSP, SMO, } \\
\text { SEM-EDS, } \\
\text { XRPD } \\
\text { CSP, SMO, } \\
\text { XRPD } \\
\text { CSP, SMO, } \\
\text { XRPD }\end{array}$ \\
SDRP4 & $\begin{array}{l}\text { Painted plaster, wall 3. } \\
\text { CSP, SMO, } \\
\text { SDRP5 }\end{array}$ & $\begin{array}{l}\text { Gilded stucco from linear } \\
\text { decoration, wall 2. } \\
\text { CRP, SMO, }\end{array}$ \\
SDRP6 & $\begin{array}{l}\text { Gilded stucco from leaf, wall 2. } \\
\text { XRPD } \\
\text { SDRP7 }\end{array}$ & $\begin{array}{l}\text { Gilded stucco from leaf, wall } 2 . \\
\text { XRPD } \\
\text { CSP, SMO, } \\
\text { XRPD }\end{array}$ \\
\hline SDRP8 & $\begin{array}{l}\text { Gilded stucco from leaf, wall 1. } \\
\text { SDRP9 }\end{array}$ & $\begin{array}{l}\text { Gilded stucco from vertical } \\
\text { frame, wall 1. }\end{array}$ \\
\hline
\end{tabular}

Table 1. samples collected from the Gabinetto of gilded stucco. CSP: cross section photomicrograph; SMO: stereo microscope

observations; SEM-EDS: scanning electron microscope observation equipped with Energy Dispersive Spectrometry; XRPD: X-ray powder diffraction.

All samples have been primarily observed with stereomicroscope and subsequently cut in cross section to obtain a view of the sequence of layers: levelling, finish, and gilding. Up to now, an elemental determination has been achieved with SEM-EDS (Jeol $5910 \mathrm{LV}$ ) for the first three samples. An example of stratigraphy with the maps of the elements is shown in figures 8,9 and 10 for
SDRP1 consisting in a layer composed by a mix of gypsum and aerial lime with traces of magnesium (a Figure 8), a lime finish (b Figure 8) followed by an alternation of different layers composed by sulphur, iron and lead, probably given by minium and iron oxides. Only few, discontinuous fragments of gold have been found, while a quite continuous organic layer - still to be examined - covers the outermost surface.

X-ray diffraction analysis (X Pan'analytical X'Pert PRO) confirmed gypsum and calcite in the levelling coat and calcite in the finish coat in SDRP1, SDRP2 and SDRP3. Gypsum has been found in SDRP4, SDRP5 and SDRP9 being the first referring to a painted finish and the second two to gypsumgilded layers. Finally SDRP6, SDRP7 and SDRP8 have a nonproperly slaked-lime due to the presence of relics of slaked lime (portlandite). Since these three samples all refer to finely molded stuccoes a correlation between such result and favorable workability may arise from further analysis. In fact, materials characterization is still under way.

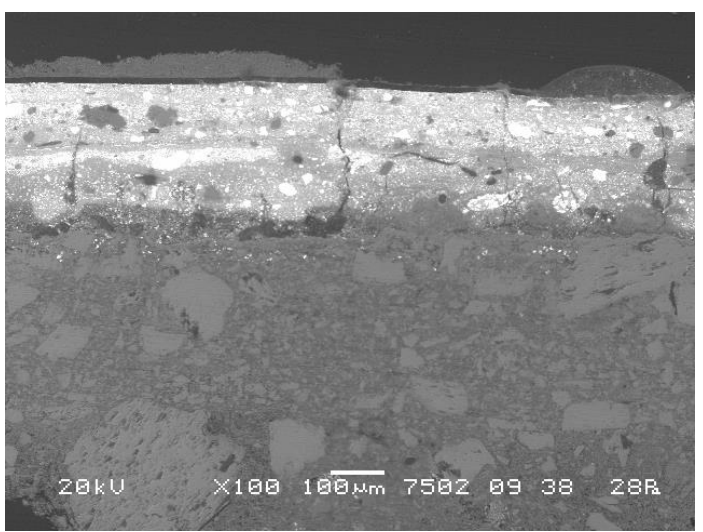

Figure 9. SEM-EDS image of sample SDRP1.
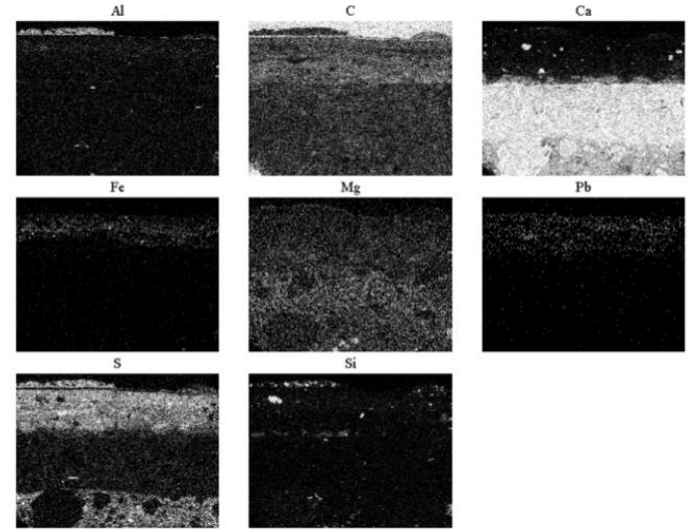

Figure 10. Map of the elements of sample SDRP1.

\section{RESULTS AND DISCUSSION}

As aforementioned, no research has been specifically devoted to traditional stucco techniques used in Naples in the 18th century or, when so, these have been studied only from a historical point of view, never verifying information directly on case studies. As a matter of fact, in order to obtain a nearly full knowledge on such artworks a multidisciplinary approach is required.

In the case of the Gabinetto, such an approach was achieved gathering data through different methods. A direct on-site observation was fundamental to make initial considerations both on the state of conservation of the room and on all the usually hidden stucco-supporting elements that extreme decay revealed 
together with some interesting marks left by the molding process. That was an important preliminary step as it was necessary to plan the following phases of the research. Furthermore, the laser scanner survey provided several orthophotos and a threedimensional model: the former suggested a general picture of the state of conservation of the room while the latter was extremely useful to make considerations on dimensional aspects connected to stucco ornaments. Thus, the archival research was unavoidable to clear dating and authorship of the works. Moreover, documents provided additional information on materials used and, sometimes, on techniques adopted to be compared to other analyses results. Finally, the multi-analytical material characterization showed differences in the composition of mortars depending on the shape they were given, on how much they were to hang out of the surfaces and how they were supposed to be held up.

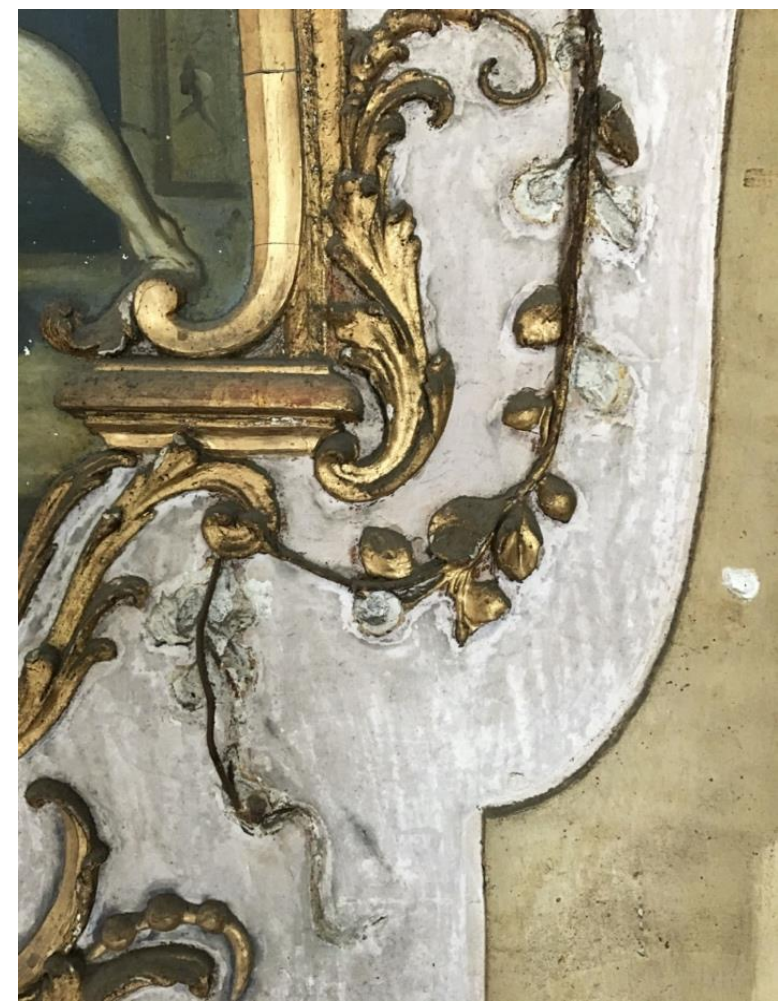

Figure 11. Wall 2: detail of the iron wires resembling stems from which leaves and blossoms hang.

Apart from the initial on-site observation, all the different research phases were pursued almost simultaneously as each step forward raised new questions which encouraged new indepth studies involving all the different disciplines. Each analysis was complementary to the others providing data which acquired a meaning when compared to the others. Therefore, crossing information obtained by the different investigations described - aiming at understanding how the ornaments were made in the Gabinetto of gilded stucco - some interesting conclusions may be drawn.

Stucco, used as surfaces' flat finish, was applied on carefully scraped keying coats (ICOMOS-ISCS 2008), as some lacunas revealing scratched substrates show. When stucco had to be molded to design ornaments, instead, procedures were consequently more elaborate. Depending on how much those decorations had to hang out of the surface, different structural elements were adopted. In the golden room for instance decayed spots clearly show two different types of such elements: the so called «stucco nails» ${ }^{9}$ which were placed at regular distances to hold stuccoes made on-site, and iron wires which were used both to hold stucco and to resemble stems from which flowers, blossoms and fruits were hanging (Figures 11 and 12). Generally in the case of on-site molded stuccoes mortars are lime-based with additions of gypsum, only-gypsum mortars were used when thin layers of flat stucco had to be applied as proven by the X-ray diffraction.

Furthermore, it is reasonable to believe that some decorative elements as flowers and blossoms were not prepared on-site but more likely in artisans' workshops. Two aspects provide evidence to this hypothesis: on one hand, one may see how elaborate they are, and it would have been not much convenient to make them on-site, moreover some of such elements once fallen have left a few millimeters deep prints. Probably these "packaged" elements were inserted in the surface and plastered with fresh bedding onsite. No casts were used since all the decorative elements, even specular ones, slightly differ in their morphology.

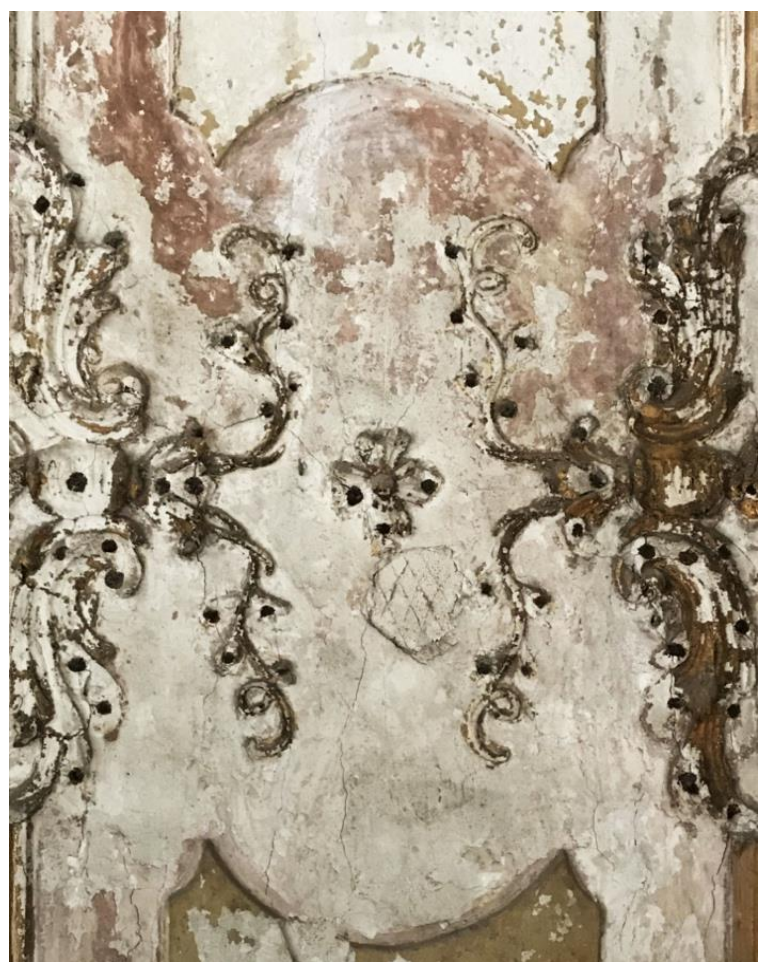

Figure 12. Wall 4: detail of the keying layer and of the iron nails used for on-site made stuccoes.

\section{CONCLUSIONS}

The present research represents a first attempt to deepen the knowledge on traditional techniques used in Naples in the $18^{\text {th }}$ century specifically concerning stucco surfaces. The experience of the study of the Gabinetto, here described, shows the usefulness of taking advantage of new technologies for a proper analysis of Neapolitan ornamental mortars which involves not only historic and architectural information - as in the majority of the publications devoted to this heritage - but many more aspects. In order to thoroughly investigate such other facets of the matter, in fact, the multidisciplinary approach proved to be very efficient to explore the issue from different points of view. Moreover, the intersection of the various expertise resulted in a quite complete knowledge of the gilded stuccoes in the room.

\footnotetext{
9 ASNa, CRA, III inv., Conti e Cautele, 1145, p. 330-351v.
} 
As shown, the method presented dealt with a macroscopic observation of the mortars, with their overall laser scanner survey, with a thorough archival research and, finally, with a multianalytical material characterization (still underway). Results obtained were synthesized returning a great advancement in the comprehension of how stuccoes were molded and gilded. However, this experience brought up also many new doubts. In particular, it is interesting to question whether or not what has been observed in the case of the Gabinetto may be extended also to a more general, common building practice conducted in Naples at that time. In other words: are the recipes followed in the composition of the stuccoes in the room and the way they vary according to their support and their thickness recurring in the mid-18th architectures? Are there other examples in which supporting elements, as iron wires in this case, were used as decorative elements? Was the mordant gilding the most diffused method to gild stuccoes? Therefore, in order to find answers to these questions and others, it will be important to always keep this multidisciplinary approach in the study of more cases regarding stuccoes made in Naples over the 18th century. The juxtaposition of similar experiences carried out at other Neapolitan architectures, in fact, will allow us to understand what the regular stucco-molding procedure was, and which solutions adopted in the Gabinetto are to be considered as more peculiar and innovative. Such kind of considerations in fact, cannot be drawn by the study of this single case, but only in relation to others. Moreover, the comparison with other Italian already examined - stucco surfaces could reveal interesting connections between different geographical contexts. This of course could lead to the achievement of a full comprehension of the stucco molding technique in the 18th century in Naples, in view of a more aware conservation of it in the future.

\section{ACKNOWLEDGEMENTS}

The present research is part of a PhD thesis in Preservation of the Architecural Heritage at the Politecnico di Milano by Damiana Treccozzi, supervised by Andrea Pane Professor of Architectural conservation at the Università degli Studi di Napoli Federico II and Antonio Sansonetti of the Consiglio Nazionale delle Ricerche (CNR), CNR-ISPC. While paragraphs 1 and 6 have been shared by the authors, paragraphs $3,4.1,4.3,5$ are by Damiana Treccozzi, paragraph 2 by Andrea Pane, paragraph 4.4 by Antonio Sansonetti and 4.2 by Raffaele Catuogno. The access to the gilded room was possible thanks to the Director of the Department of Agriculture of the Università degli Studi di Napoli Federico II Professor Matteo Lorito and Dr. Adriana Forlani while the SEM-EDS analysis was made by Danilo Biondelli of the Consiglio Nazionale delle Ricerche (CNR), CNR-ISPC.

\section{REFERENCES}

Allroggen-bedel, A., Kammerer-grothaus, H., 1983. Il museo ercolanese di Portici. La Villa dei Papiri. Cronache Ercolanesi, Supplemento 2, p. 83-128.

Arcolao, C., 1998. Le ricette del restauro. Malte, intonaci, stucchi dal XV al XIX secolo. Marsilio, Venezia.

Aveta, A., 1987. Materiali e tecniche tradizionali nel napoletano. Note per il restauro architettonico, Arte Tipografica, Napoli.

Bordiga, O., 1906. Il palazzo della R. Scuola Superiore di Agricoltura in Portici e la sua storia. Le vicende della Scuola. I locali ed i terreni annessi. Stab. tip. vesuviano, Portici.

Carbonara, G., Palazzo, M., (eds), 2012. La sala delle cariatidi nel Palazzo reale di Milano: ricerche e restauro. Gangemi, Roma.
Carotenuto V., 1998. Documenti dell'Archivio di Stato di Napoli. La Reggia di Portici nelle collezioni d'arte tra Sette e Ottocento. Elio de Rosa, Portici, p. 49-62.

Casiello, S., 2005. Le cupole in Campania. Indagini conoscitive e problemi di conservazione. Arte tipografica, Napoli.

Del Pezzo, N., 1896: Siti reali: il palazzo reale di Portici. Napoli Nobilissima, vol. V, fasc. XI, 161- 167, 183-188.

De Seta, C., Di Mauro, L., Perone, M., 1980. Ville vesuviane. Rusconi immagini, Milano.

Doglioni, F., Scappin, L., Squassina, A., 2017. Conoscenza e restauro degli intonaci e delle superfici murarie esterne di Venezia. Campionature, esemplificazioni, indirizzi di intervento. Il Prato, Saonara.

Donadono, L., Picone, R., Romeo, E., Rosi, M., 1990. Il colore della Napoli neoclassica: intonaci, stucchi e finti marmi, Superfici dell'Architettura: le Finiture. Libreria Progetto, Padova, p. 597627.

Ente Ville Vesuviane 1977, Le ville vesuviane. Arti grafiche Boccia, Salerno.

Fiengo, G., Guerriero, L. 1999. Murature tradizionali napoletane. Cronologia dei paramenti tra il XVI ed il XIX secolo. Arte tipografica, Napoli.

Fiengo, G., Guerriero, L. 2008. Atlante delle tecniche costruttive tradizionali. Arte tipografica, Napoli.

Fratta, A., 2004. Il Patrimonio architettonico dell'Ateneo Fridericiano. Arte tipografica, Napoli.

Grimoldi, A., 2014. Sostenibilità, tutela, nuovi orizzonti della ricerca storica. Scienza e Beni Culturali XXX. 2014. Quale sostenibilità per il restauro? Ediz. Arcadia Ricerche, Venezia.

ICOMOS-ISCS, 2008. Illustrated glossary on stone deterioration patterns. Monuments and Sites, XV, p. 1-78.

Mannoni, T., 2003. Cultura artistica e cultura materiale. Proposte per conoscere meglio qualcosa del passato. III Congresso Nazionale di Archeologia Medioevale. All'insegna del giglio, Firenze, p. 9-13.

Martorelli, L., 1998. La Reggia di Portici nell'Ottocento. Arredi e trasformazioni in epoca neoclassica. La Reggia di Portici nelle collezioni d'arte tra Sette e Ottocento. De Rosa, Portici, p. 15-32.

Rampazzi, L., Rizzo, B., Colombo, C., Conti, C., Realini, M., Bartolucci, U., Colombini, M. P., Spiriti, A., Facchin, L., 2008. The stucco decorations from St. Lorenzo in Laino (Como, Italy): The materials and the techniques employed by the "Magistri Comacini”. Analytica Chimica Acta, 630, 1, 91-100.

Russo, V., 2005. Finiture superficiali nel cantiere napoletano del Settecento. Il colore dell'edilizia storica. Gangemi, Roma, p. 100106.

Sansonetti, A., Striova, J., Biondelli, D., Aliatis, I., Rampazzi, L., 2016. Hidden colours in stuccowork damaged by fire: a multianalytical investigation for revealing the original decorative pattern. Journal of Cultural Heritage, 22, 1055-1060.

Santoro, L., 1959. Il Palazzo Reale di Portici. Ville vesuviane del Settecento. Edizioni scientifiche italiane, Napoli, 193-235. 